\title{
ATP2C2 Gene
}

National Cancer Institute

\section{Source}

National Cancer Institute. ATP2C2 Gene. NCI Thesaurus. Code C94685.

This gene plays a role in active transport. 